\title{
Distributional patterns of non-marine Ostracoda (Crustacea) in Adiyaman Province (Turkey)
}

\author{
Mehmet Yavuzatmaca*, Okan Külköylüoğlu and Ozan Yılmaz \\ Department of Biology, Faculty of Arts and Science, Abant İzzet Baysal University, 14280 Bolu, Turkey
}

Received 13 October 2014; Accepted 30 December 2014

\begin{abstract}
To understand the distribution and ecological characteristics of non-marine ostracods, the Poisson Method was applied to a total of 41 taxa (26 recent and 15 sub-fossil) from 111 (out of 120) aquatic bodies of Adiyaman Province, Turkey. All taxa were new records for the area and Schellencandona insueta and Gomphocythere n. sp. were the first records for Turkey. According to the Poisson method, ostracods were randomly distributed among all sampling sites $(P>0.05)$. This is especially true for the cosmopolitan species (Candona neglecta, Heterocypris incongruens, Ilyocypris bradyi and Psychrodromus olivaceus) with broader ecological tolerance ranges to different environmental variables. According to canonical correspondence analysis (CCA), the first two axes explained $77.4 \%$ of the relationships and the most effective variables were found as electrical conductivity $(F=3.987, P=0.002, \lambda=0.31)$, water temperature $(F=3.582, P=0.002$, $\lambda=0.17), \mathrm{pH}(F=3.510, P=0.002, \lambda=0.12)$ and elevation $(F=4.491, P=0.02, \lambda=0.37)$. Additionally, the ratio (numbers of taxa/site $=2$ ) was found same at lower $(450-550 \mathrm{~m})$ and higher $(1359-1459 \mathrm{~m})$ ranges, in which $H$. incongruens and $I$. bradyi were the most common species found from different habitats. Overall, random distribution of ostracods among sampling sites seemed to be more affected by random distribution of cosmopolitan species at the regional level than the non-cosmopolitans whose distribution may be uniform or clumped since they prefer certain types of ecological conditions at local level.
\end{abstract}

Key words: Ostracoda / Poisson distribution / optima and tolerance / elevation / cosmopolitan

\section{Introduction}

One of the important characteristics of ecological communities is the spatial patterns of animals and plants because individuals take up space in different forms (Heip, 1975; Ludwig and Reynolds, 1988). The three types of spatial patterns are random, clumped (aggregation) and uniform distribution. A random distribution implies that all individuals have equal probability of occurring anywhere in a habitat. When species are equally spaced throughout an environment or aggregated in an area of favourable conditions, they are considered to have uniform or clumped distributions, respectively (Ludwig and Reynolds, 1988). This spacing of individuals in their environment may be explained by the habitat homogeneity/heterogeneity, nonselective behaviour, social behaviour, reproductive mode, competition, physico-chemical variables of aquatic environments, habitat preferences and human effect on habitats (Gabbutt, 1961; Ludwig and Reynolds, 1988; Kan, 2006; Kiss, 2007; González-Megías et al., 2011). Hence, it can be

\footnotetext{
*Corresponding author: yavuzatmaca_m@ibu.edu.tr
}

summarized as the biotic and abiotic factors affecting the usage of space by individuals. The "Poisson Distribution" method (Heip, 1975) is commonly used for estimating the type of distribution displayed by species of interest. In 1837, Siméon Dennis Poisson defined the "Poisson distribution" model as a random distribution with the population variance $\left(s^{2}\right)$ equal to the mean $(\mu)$ (Ludwig and Reynolds, 1988; Zar, 1999; Kan, 2006).

The other types of distribution (uniform and clumped) are found by measuring the amount when the ratio of variance to mean departs from random distribution values. Based on this ratio $\left(s^{2} / \mu\right)$, several types of the indices of dispersion have been proposed such as Green's index, index of dispersion, index of clumping, standardized Morisita index (Morisita, 1959; Ludwig and Reynolds, 1988). Among them, the index of dispersion is widely used (Heip, 1976) to predict uniform and clumped distribution. Accordingly, if $s^{2} / \mu=1$ (Poisson distribution), organisms (or population) show a random distribution, but if $s^{2} / \mu>1$ (negative binomial), they display a clumped pattern. When $s^{2} / \mu<1$ (positive binomial), a uniform pattern is being exhibited. 
Ostracods (Crustacea) are small bivalved aquatic invertebrates and one of the oldest living microfauna first recorded back in the Cambrian period (Delorme, 1991; Meisch, 2000). They inhabit a variety of aquatic bodies ranging from fresh to saline waters (e.g., lakes, troughs (like narrow canal designed to hold water), ponds, springs, caves) (Delorme, 1991; Yavuzatmaca et al., 2012; Külköylüoğlu et al., 2013) and are used as bio-indicator of water quality (Delorme, 1991). Published studies are available describing ostracod habitat preferences (Benzie, 1989; Dügel et al., 2008), habitat similarities (Sar1 and Külköylüoğlu, 2010), and ecology and distribution (Teeter, 1973; Malmqvist et al., 1997; Mezquita et al., 1999; Kiss, 2007; Pieri et al., 2009; Van der Meeren et al., 2010; Külköylüoğlu et al., 2013). However, with the exception of Heip (1976), there is no specific research on the distributional patterns of ostracods using Poisson probabilities. Heip (1976) attempted to test the spatial pattern of a single species (Cyprideis torosa (Jones, 1850)) in a small brackish pond in Northern Belgium during a single sampling event in January 1971. He concluded that C. torosa showed aggregated distribution in this pond. In contrast, the present study covers many species of ostracods occurring in a wide geographical area within several different types of aquatic habitats where application of Poisson probabilities were suitable.

There are about 140 non-marine free-living freshwater ostracods have been reported from Turkey (Külköylüoğlu, 2013; unpublished data). This number of ostracods in Turkey is higher than in Germany (126 spp.), Great Britain (90 spp.), Austria (81 spp.) and Belgium (71 spp.) but lower than in Italy (151 spp.) (for more details see Pieri et al., 2013) and India (152 spp.) (Karuthapandi et al., 2014). However, we believe that numbers of Turkish nonmarine ostracods are underestimated because of lack of information about ostracod diversity from other regions of Turkey. Until the present study, such knowledge was also scarce for Adiyaman region, where there was no extensive study on ostracods. The main objectives of this study are: (i) to test the hypothesis of Poisson as "Ostracods are randomly distributed among sampling sites in Adiyaman Province"; (ii) to determine the importance of regional (spatial) or local factors on the ostracod assemblages; and (iii) to contribute knowledge into the ostracod fauna of Adiyaman Province along with estimating ecological optimum and tolerance levels of individual species for different ecological variables.

\section{Material and methods}

\section{Site description}

Adiyaman is located in the middle of Euphrates (south east of Turkey) between $38^{\circ} 11^{\prime}-37^{\circ} 25^{\prime} \mathrm{N}$ and $39^{\circ} 14^{\prime}-37^{\circ} 31^{\prime} \mathrm{E}$, covering about $7164 \mathrm{~km}^{2}$ of surface area. The north part of the city is surrounded by the Malatya Mountains that are the extensions of Toros Mountains. The south part elevation begins to decrease to the lowland plain. Southern parts are usually hot and dry during summer season, whereas northern parts are cooler and dry during winter season. The minimum and maximum air temperature of summer and winter fluctuate between 28-47 and -10 to $10^{\circ} \mathrm{C}$, respectively (Adıyaman valiliği, 2014).

\section{Sampling and measurements}

Total of 120 samples were collected from randomly selected 12 types of aquatic bodies (limnocrene, rheocrene and helocrene springs, lake, dam, pond, pool, creek, stream, water fall, irrigation canal and troughs) in Adiyaman Province during 16-19 July 2012 (Fig. 1). At each site, environmental variables, including dissolved oxygen $\left(\mathrm{mg} . \mathrm{L}^{-1}\right)$, per cent oxygen saturation ( $\%$ sat.), water temperature $\left({ }^{\circ} \mathrm{C}\right)$, electrical conductivity $\left(\mu \mathrm{S} . \mathrm{cm}^{-1}\right)$, total dissolved solids (TDS) $\left(\mathrm{mg} . \mathrm{L}^{-1}\right)$, salinity (ppt), $\mathrm{pH}$ and atmospheric pressure $(\mathrm{mmHg})$ were recorded by YSIProfessional Plus. A Testo 410-2 model anemometer was used to obtain air temperature $\left({ }^{\circ} \mathrm{C}\right)$, wind speed $\left(\mathrm{km} \cdot \mathrm{h}^{-1}\right)$ and air moisture $(\%)$, while basic geographical data (elevation, coordinates) were recorded with a geographical positioning system (GARMIN etrex Vista H GPS) in situ. All of the physico-chemical variables of aquatic habitats were measured before sampling for ostracods to prevent possible results of pseudoreplication (Hurlbert, 1984). Ostracod samples collected from each site with a standard sized hand net ( $200 \mu \mathrm{m}$ mesh size) were stored in $250 \mathrm{~mL}$ plastic bottle and fixed with $70 \%$ alcohol in situ.

In the laboratory, each sample was filtered through four standard sized sieves $(0.5,1.0,1.5$ and $2.0 \mathrm{~mm}$ mesh size) under tap water and then preserved in $70 \%$ alcohol for further studies. Ostracod specimens were picked up from sediments under a stereomicroscope and the soft body parts were dissected in lactophenol solution for taxonomic identification. Carapace and valves were kept in micropalaeontological slides for further use. The taxonomic key of Meisch (2000) was primarily used for taxonomic classification and species identification, supplemented with Bronhstein (1947) and Karanovic (2012) when needed. All of the ostracod samples were stored in the Limnology Laboratory of Abant İzzet Baysal University Bolu, Turkey and are available upon request.

\section{Statistical analysis}

The hypothesis of a random pattern of Poisson distribution (versus aggregated and uniform distribution) was tested by the application of Poisson probabilities along with chi-square test. Using the number of species collected in each site, the observed number of sites (f) that harbour $0,1,2,3,4$ or more $(4+)$ species was computed (Fig. 2). The mean $(\mu)$ was calculated by multiplying the number of species (i.e., $0,1, \ldots, 4+$ ) by the numbers of sites where they observed, then dividing by the total number of sampling sites (Ludwig and Reynolds, 1988). Then, the Poisson probability of $x$ occurrences ( $x$ represents the number of species in a habitat as $0,1,2,3,4+)$ in a 


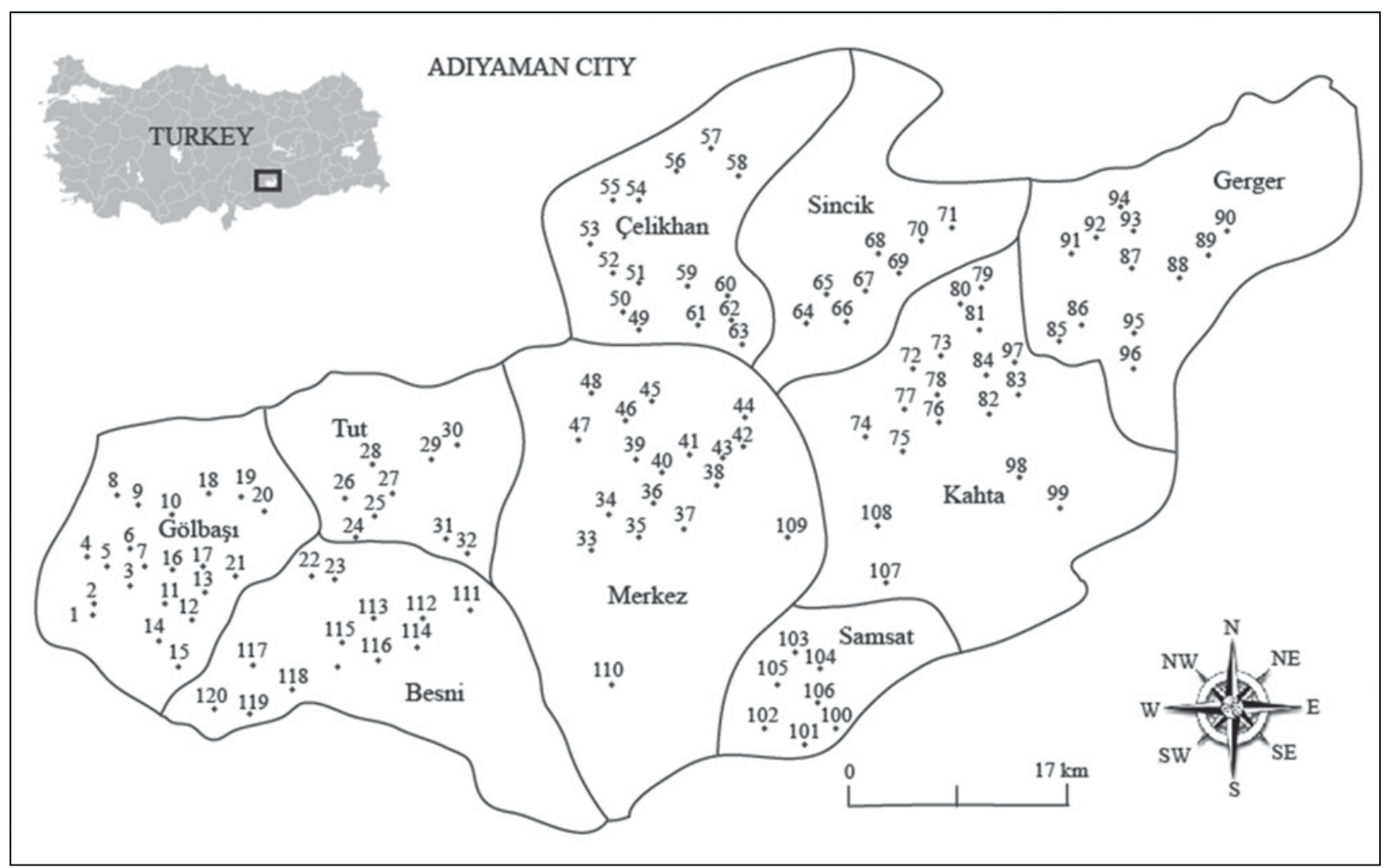

Fig. 1. The distribution of 120 randomly selected sample sites from 9 (Gölbaşı, Tut, Besni, Merkez, Samsat, Kahta, Gerger, Sincik and Çelikhan) counties of Adiyaman Province, Turkey.

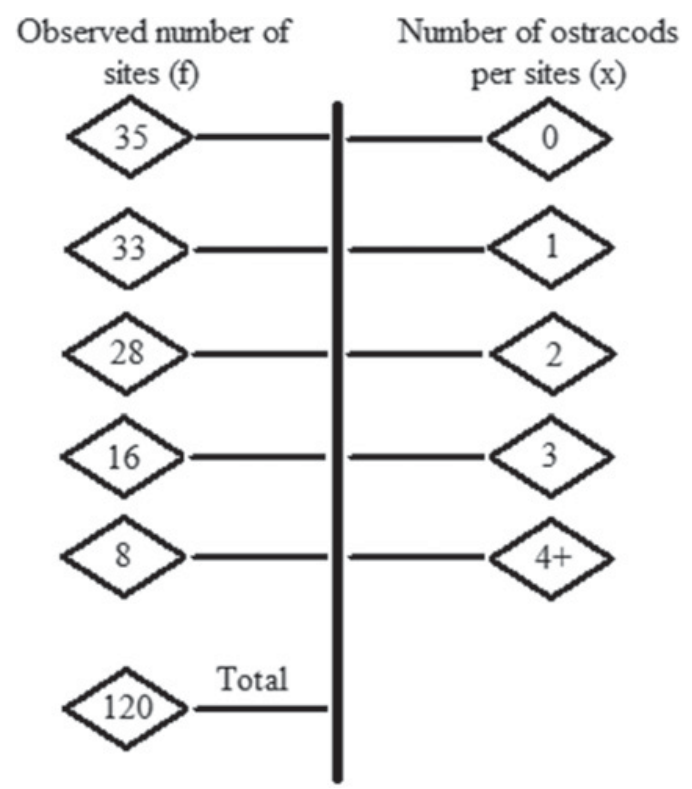

Fig. 2. The number of sites carrying $0,1,2,3,4$ or more $(4+)$ occurrences of ostracod species (not including empty valves and carapaces).

sampling unit $P(x)$ was calculated by equation (1) (Table 1) as

$$
P(x, \mu)=\frac{\mu^{X} e^{-\mu}}{X !}
$$

where $e$ is the Euler's number and is equal to approximately 2.71828 ; $\mu$ the mean number of successes that occur
Table 1. Poisson probabilities of $0,1,2,3,4(+)$ occurrences of ostracod species calculated using equation (1).

\begin{tabular}{ll}
\hline$P(x=0)$ probability of no occurrence & 0.2446 \\
$P(x=1)$ probability of one occurrence & 0.3444 \\
$P(x=2)$ probability of two occurrences & 0.2425 \\
$P(x=3)$ probability of three occurrences & 0.1139 \\
$P(x=4+)$ probability of four $(+)$ occurrences & 0.0401 \\
\hline
\end{tabular}

in a specified region; $x$ the actual number of successes that occur in a specified region; $P(x ; \mu)$ the Poisson probability that exactly $x$ successes occur in a Poisson experiment, when the mean number of successes is $\mu$.

In addition, hypothesis testing of Poisson distribution can also be done with a chi-square $\left(\chi^{2}\right)$ statistic (if $N>30$ ) (Ludwig and Reynolds, 1988) which is used to investigate whether distributions of observed frequencies $(O)$ differ from expected frequencies $(E)$ of the actual number of successes that occurs in a sampling unit (equation 2, Table 2). Expected probabilities were counted by total samples times with Poisson probability of each occurrences $(P(x=0), P(x=1), P(x=2), P(x=3), P(x=4+))$ which were given in Table 2 . Thus, chi-square is computed by the following equation (2),

$$
\chi^{2}=\sum_{n=0}^{n} \frac{(O-E)^{2}}{E}
$$

Finally, the departure from Poisson distribution was tested by application of the index of dispersion $\left(s^{2} / \mu\right)$. The other test statistics for $d$ (equation (4)) when the total 
Table 2. The calculated chi-square values of five different classes (chi-square test was used to compare observed $(O)$ and expected $(E)$ frequencies). Expected frequency $=N \times$ Poisson Probability; five classes with two constants (habitat and species) so degrees of freedom $=n-2=5-2=3^{*}$; chi-square $=\sum(O-E)^{2} / E$.

\begin{tabular}{lllcrrr}
\hline Class & $x$ & Obs. Freq. & Exp. Freq. & $O-E$ & $(O-E)^{2}$ & $(O-E)^{2} / E$ \\
\hline 1 & 0 & 35 & 29.35 & 5.65 & 31.97 & 69.37 \\
2 & 1 & 33 & 41.33 & -8.33 & 1.09 & 1.68 \\
3 & 2 & 28 & 29.10 & -1.10 & 0.04 \\
4 & 3 & 16 & 13.66 & 3.34 & 5.47 & 0.40 \\
5 & 4 & 8 & 4.81 & $\left(\chi^{2}\right)$ & 2.19 & 10.17 \\
& & $N=120$ & & & 5.33 \\
\hline
\end{tabular}

Table 3. Summary of CCA. First two axes explain $77.4 \%$ of relationships between species and environmental variables of total variance.

\begin{tabular}{|c|c|c|c|c|c|}
\hline$\overline{\text { Axes }}$ & 1 & 2 & 3 & 4 & Total inertia \\
\hline$\overline{\text { Lengths of gradient }{ }^{\mathrm{a}}}$ & 5.14 & 3.44 & 2.89 & 4.70 & \\
\hline Eigenvalues & 0.32 & 0.18 & 0.12 & 0.02 & 4.57 \\
\hline Species-environment correlations & 0.71 & 0.53 & 0.48 & 0.23 & \\
\hline \multicolumn{6}{|l|}{ Cumulative percentage variance } \\
\hline Of species data & 6.9 & 10.8 & 13.4 & 13.9 & \\
\hline Of species-environment relation & 49.6 & 77.4 & 96 & 99.4 & \\
\hline Sum of all eigenvalues & & & & & 4.57 \\
\hline Sum of all canonical eigenvalues & & & & & 0.64 \\
\hline
\end{tabular}

aShows the results of DCA (if the value of DCA is $\geq 3$, data are suitable for the usage of CCA for more see ter Braak, 1987; Birks et al., 1990).

sample size $\geq 30$ were used to measure the departure of index of dispersion (ID) from 1.0. The value of $d$ statistic was also calculated by equation (4) for measuring the agreement with Poisson. Before calculation of $d$ statistics, the value of chi-square $\left(\chi^{2}\right)$ is computed by equation (3).

$$
\chi^{2}=\mathrm{ID}(N-1)
$$

where $\chi^{2}$ is chi-square, $N$ the total sample size; ID the index of dispersion.

$$
d=\sqrt{2 \chi^{2}}-\sqrt{2(N-1)-1}
$$

where $\chi^{2}$ from equation (3).

Canonical correspondence analysis (CCA) was used to examine relationships between 11 species (with 3 or more occurrences during the study) and the 5 most commonly used environmental variables (electrical conductivity (EC), water temperature (Tw), dissolved oxygen (DO), $\mathrm{pH}$ and elevation (Elev.)). All data were log-transformed (ter Braak, 1987; Birks et al., 1990) and tested with Monte Carlo Permutation tests (499), where rare species were eliminated from analysis to prevent the effect of multicolinearity and arc-effect (software package CANOCO for windows 4.5). We used C2 software (Juggins, 2003) to estimate species tolerance $\left(t_{k}\right)$ and optimum $\left(\mu_{k}\right)$ levels for different ecological variables after using a transfer function of weighted averaging regression. During the analysis, living adults (specimens with undamaged soft body parts and carapaces when collected) were used. The Alpha diversity indices (i.e., Shannon-Wiener Diversity) of different habitat types were calculated using the Species Diversity and Richness 4 software (Seaby and Henderson, 2006). Microsoft Excel 2010 was also used to draw the relationships among numbers of taxa per sampled sites.

\section{Results}

A total of 41 ostracod taxa (26 recent and 15 sub-fossil (empty valves and carapaces)) were reported from 111 of 120 randomly selected aquatic bodies (see the Appendix). To our knowledge all of these taxa are new reports for the region. Living (recent) forms of Schellencandona insueta (Klie) and Gomphocythere n. sp. (in preparation) are new records for the Turkish Ostracoda fauna.

The Poisson probabilities of $P(x=0), \quad P(x=1)$, $P(x=2), P(x=3)$ and $P(x=4+)$ occurrences were calculated by equation (1) are like that $0.2446,0.3444,0.2425$, 0.1139 and 0.0401 , respectively (Table 1$)$. Accordingly, the expected probabilities of them (e.g., $P(x=0), P(x=1), \ldots$, $P(x=4+)$ were founded as follows $29.35,41.33,29.10$, 13.66 and 4.81 , respectively (Table 2$)$. The chi-square $\left(\chi^{2}\right)$ table value $(7.81)$ at the $5 \%$ probability level (degrees of freedom $($ d.f. $)=3$ ) is larger than $\chi^{2}$ calculated (5.33) (Table 2) so the result is not significant and we accepted the random distribution hypothesis. After the application of Poisson method, the variance $\left(s^{2}\right)=1.508$ and mean $(\mu)$ of the observed frequencies counts $=1.408$ resulting in the ratio of $s^{2} / \mu=1.06$. This ratio was found slightly larger than 1.0 which was not a significant $(P>0.05)$ difference suggesting a random distribution of ostracods among sampling sites. The results of $d$ statistic (0.488) also support a random distribution of ostracods in Adiyaman Province.

The first two axes of CCA diagram explained $77.4 \%$ (Table 3 ) with relatively high variance $(10.8 \%$ ) of the relationships between 11 species and 5 environmental variables (Fig. 3). Based on the effectiveness, electrical conductivity $(F=3.987, \quad P=0.002, \quad \lambda=0.31)$, water 


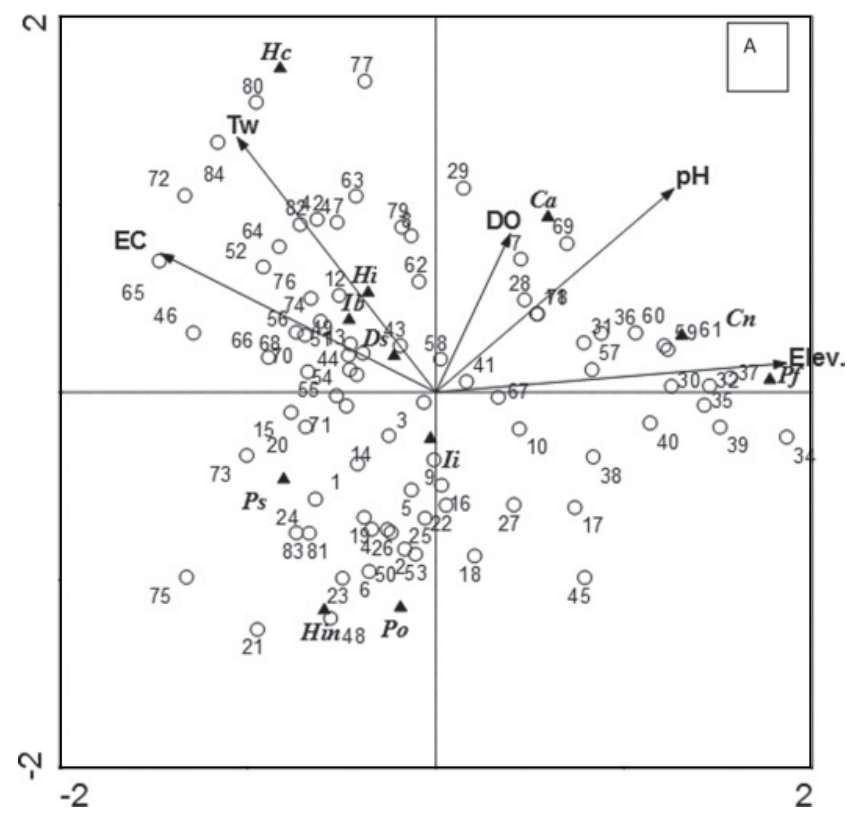

Fig. 3. CCA diagram shows the effect of the five most important environmental variables (arrows) on the distribution of 11 species with 3 or more occurrences from 83 sampling sites. Triangles show the species code, whereas open circles (o) represent the sites number. DO (dissolved oxygen, mg. $\mathrm{L}^{-1}$ ), EC (electrical conductivity, $\mu \mathrm{S} . \mathrm{cm}^{-1}$ ), Tw (water temperature, ${ }^{\circ} \mathrm{C}$ ) and Elev. (elevation, $\mathrm{m}$ ). See the Appendix for codes of species.

temperature $\quad(F=3.582, \quad P=0.002, \quad \lambda=0.17), \quad \mathrm{pH}$ $(F=3.510, P=0.002, \lambda=0.12)$ and elevation $(F=4.491$, $P=0.02, \lambda=0.37)$ seemed to be the most important factors on species while dissolved oxygen $(F=0.967$, $P=0.37, \lambda=0.08)$ did not show any significant effect. Three species (Candona angulata Müller, Candona neglecta Sars, Potamocypris fallax Fox) located on the right upper part of the CCA diagram (Fig. 3) showed a positive correlation to dissolved oxygen, $\mathrm{pH}$ and elevation, while four species (Heterocypris incongruens (Ramdohr), Darwinula stevensoni (Brady and Robertson), Herpetocypris chevreuxi (Sars), Ilyocypris bradyi Sars) placed on the opposite side seemed to have a close relationship to water temperature and electrical conductivity. The other species (Psychrodromus olivaceus (Brady and Norman), Herpetocypris intermedia (Kaufmann), Potamocypris similis G.W. Müller, Ilyocypris inermis Kaufmann) did not show a direct correlation to the variables used.

The ecological tolerance and optimum levels of the most frequently occurring eight species to different environmental variables indicated that species with cosmopolitan characteristics (e.g., C. neglecta, H. incongruens, I. bradyi and P. olivaceus) tend to have broader tolerance ranges than those of the non-cosmopolitan species (Table 4 ).

Among the sampling sites, springs $(H=2.32)$, creeks $(H=2.19)$ and ponds $(H=2.10)$ displayed higher Shannon diversity values where numbers of species encountered were also higher than the other habitats (Table 5). Although we did not recognize particular habitat preferences of some of those well-known cosmopolitan species (e.g., H. incongruens, I. bradyi), it appeared that most non-cosmopolitans with low occurrence frequency (e.g., Fabaeformiscandona brevicornis (Klie), $P$. fulva (Brady), etc.) showed tendency for habitat preferences with specific local factors (e.g., $\mathrm{pH}, \mathrm{DO})$. The ratio of the numbers of taxa per site $(=2)$ was not significantly different between lower $(450-550 \mathrm{~m})$ and higher (1359-1459 m) elevational ranges (Fig. 4).

\section{Discussion}

This is the first comprehensive study in Adiyaman Province resulting in all taxa (41 ostracod taxa) being new reports for the region. Although it may seem like a high diversity, the number of recent species (26) in Adiyaman (with $7164 \mathrm{~km}^{2}$ surface area) is lower than the diversity of cities nearby such as Van (30 species; with $21334 \mathrm{~km}^{2}$ surface area) (Külköylüoğlu et al., 2012a), Diyarbakır (29 species, with $15272 \mathrm{~km}^{2}$ surface area) (Akdemir and Külköylüoğlu, 2011) and Kahramanmaraş (32 species, $14346 \mathrm{~km}^{2}$ surface area) (Külköylüoğlu et al., 2012b). In spite of we sampled each site only once during a 4-day period in July 2012, many species were collected from a variety of habitats, thus providing important contributions towards ostracod distribution and ecology. For example, finding $S$. insueta and a new species of genus Gomphocythere Sars (in preparation) was of significance for their distribution in Turkey. The presence of living species of Gomphocythere has been known to be restricted to mostly big lakes in Africa and a river in Israel (Martens, 1993). Most recently, Boomer and Gearey (2010) reported a fossil species, Gomphocythere geareyi from Domuztepe region (Kahramanmaraş, Turkey). This was the most northern record of the genus so far but the finding of Gomphocythere n. sp. from Besni (Adiyaman) changed its distribution to the north-east part of Domuztepe.

After testing the Poisson probabilities, we found random distributions of ostracods in the study area. However, our value of index of dispersion suggested a clumped distribution. This brings out a critical controversy on species distribution. According to Elliott (1973) if the absolute $d$ value is smaller than 1.96 (or $\mathrm{I} d \mathrm{I}<1.96$ ), a population shows random dispersion, but if $d<-1.96$ or $d>1.96$, the distribution can be uniform or clumped, respectively. In our case, since the $d$ statistic value $(0.488)$ was smaller than 1.96 , the distribution of ostracods were random, considering that the 0.06 difference is not statistically significant departure from 1.0.

Similar results of random distribution have already been reported for other taxonomic groups such as fleas (aphids) on leaves and some sessile invertebrates (Gabbutt, 1961; Schmidt, 1982), when some studies have revealed clumped distribution for some freshwater (Heip, 1976), marine benthic (Heip, 1975) and some sessile invertebrates (Schmidt, 1982). All of these spatial patterns of invertebrates may be explained by individual species habitat preferences affected by biotic and/or abiotic 
Table 4. The optimum $\left(u_{\mathrm{k}}\right)$ and tolerance $\left(t_{\mathrm{k}}\right)$ levels of eight species (with five or more occurrences) to four different ecological variables. $N_{2}$ represents Hill's coefficient value (measure of effective number of occurrences). DO (dissolved oxygen, mg. ${ }^{-1}$ ), EC (electrical conductivity, $\mu \mathrm{S} . \mathrm{cm}^{-1}$ ) and Tw (water temperature, ${ }^{\circ} \mathrm{C}$ ).

\begin{tabular}{|c|c|c|c|c|c|c|c|c|c|c|c|}
\hline \multirow[b]{2}{*}{ Species } & \multirow[b]{2}{*}{ Count } & \multirow[b]{2}{*}{ Max } & \multirow[b]{2}{*}{$\mathrm{N}_{2}$} & \multicolumn{2}{|c|}{$\mathrm{pH}$} & \multicolumn{2}{|c|}{$\mathrm{DO}$} & \multicolumn{2}{|c|}{$\mathrm{EC}$} & \multicolumn{2}{|c|}{ Tw } \\
\hline & & & & $u_{k}$ & $t_{k}$ & $u_{k}$ & $t_{k}$ & $u_{k}$ & $t_{k}$ & $u_{k}$ & $t_{k}$ \\
\hline I. inermis & 21 & 87 & 11.67 & 7.95 & 0.37 & 7.01 & 1.27 & 441.38 & 96.89 & 19.64 & 4.74 \\
\hline H. incongruens & 46 & 89 & 10.97 & 7.93 & 0.31 & 8.00 & 1.81 & 500.28 & 230.83 & 22.47 & 6.21 \\
\hline I. bradyi & 25 & 103 & 7.47 & 7.96 & 0.45 & 7.46 & 3.22 & 570.41 & 164.62 & 22.36 & 4.28 \\
\hline P. fallax & 15 & 93 & 7.00 & 8.32 & 0.21 & 8.31 & 0.79 & 256.62 & 78.45 & 17.58 & 1.68 \\
\hline P. olivaceus & 15 & 97 & 6.29 & 7.79 & 0.25 & 6.55 & 1.01 & 424.30 & 91.98 & 17.90 & 3.37 \\
\hline C. neglecta & 6 & 21 & 3.65 & 8.36 & 0.36 & 7.93 & 1.09 & 342.49 & 134.38 & 18.84 & 2.74 \\
\hline H. intermedia & 10 & 107 & 2.86 & 7.83 & 0.32 & 6.23 & 1.87 & 323.06 & 127.86 & 20.74 & 2.58 \\
\hline \multirow[t]{4}{*}{ H. chevreuxi } & 5 & 21 & 2.80 & 8.33 & 0.56 & 8.83 & 1.43 & 421.53 & 128.86 & 30.60 & 4.13 \\
\hline & & & Mean & 8.06 & 0.36 & 7.54 & 1.56 & 410.01 & 131.73 & 21.27 & 3.72 \\
\hline & & & Max. & 8.36 & 0.56 & 8.83 & 3.22 & 570.41 & 230.83 & 30.60 & 6.21 \\
\hline & & & Min. & 7.79 & 0.21 & 6.23 & 0.79 & 256.62 & 78.45 & 17.58 & 1.68 \\
\hline
\end{tabular}

Table 5. The occurrence of 26 species in nine different aquatic bodies. Springs include three spring types as limnocrene, rheocrene and helocrene.

\begin{tabular}{|c|c|c|c|c|c|c|c|c|c|c|}
\hline Species & Code & $\begin{array}{c}\text { Spring } \\
(n=44)\end{array}$ & $\begin{array}{c}\text { Creek } \\
(n=22)\end{array}$ & $\begin{array}{c}\text { Pond } \\
(n=26)\end{array}$ & $\begin{array}{l}\text { Irrigation } \\
\text { c. }(n=6)\end{array}$ & $\begin{array}{l}\text { Trough } \\
(n=11)\end{array}$ & $\begin{array}{c}\text { Dam } \\
(n=3)\end{array}$ & $\begin{array}{c}\text { Stream } \\
(n=4)\end{array}$ & $\begin{array}{c}\text { Lake } \\
(n=3)\end{array}$ & $\begin{array}{c}\text { Water } \\
\text { f. }(n=1)\end{array}$ \\
\hline C. angulata & $\mathrm{Ca}$ & & 1 & 2 & & & & & & \\
\hline C. neglecta & $\mathrm{Cn}$ & 5 & & & 1 & & & & & \\
\hline D. stevensoni & Ds & 1 & & 1 & & & 1 & & & \\
\hline F. brevicornis & $\mathrm{Fb}$ & 1 & & & & & & & & \\
\hline H. brevicaudata & $\mathrm{Hb}$ & & 1 & & 1 & & & & & \\
\hline H. chevreuxi & $\mathrm{Hc}$ & 1 & 1 & 3 & & & & & & \\
\hline H. helenae & $\mathrm{Hh}$ & & 1 & & & & & & & \\
\hline H. intermedia & Hin & 5 & 1 & 3 & & 1 & & & & \\
\hline H. incongruens & $\mathrm{Hi}$ & 16 & 8 & 7 & 4 & 6 & 1 & 2 & & 1 \\
\hline I. bradyi & $\mathrm{Ib}$ & 10 & 8 & 1 & 2 & 1 & 2 & 1 & & \\
\hline I. gibba & $\mathrm{Ig}$ & & & & & & 1 & & & \\
\hline I. inermis & $\mathrm{Ii}$ & 10 & 4 & 6 & 1 & & & & & \\
\hline Gomphocythere n. sp. & $\mathrm{Gb}$ & 1 & & & & & & & & \\
\hline L. inopinata & $\mathrm{Li}$ & & & & 1 & & 1 & & & \\
\hline P. fallax & $\mathrm{Pf}$ & 6 & 7 & & 1 & 1 & & & & \\
\hline P. fulva & Pfu & 1 & & & & & & & & \\
\hline P. pallida & $\mathrm{Pp}$ & & & & & 1 & & & & \\
\hline P. similis & Ps & 1 & 1 & & & 1 & & & & \\
\hline P. smaragdina & Psm & & 2 & & & & & & & \\
\hline$P$. variegata & $\mathrm{PV}$ & & & 1 & & & & & & \\
\hline P. albicans & $\mathrm{Pa}$ & 1 & & 1 & & & & & & \\
\hline P. semicognita & Pse & & 1 & & & & & & & \\
\hline P. olivaceus & Po & 11 & 2 & 1 & & 1 & & & & \\
\hline S. insueta & $\mathrm{Si}$ & 1 & & & & & & & & \\
\hline T. clavata & $\mathrm{Tc}$ & 1 & & 1 & & & & & & \\
\hline \multirow[t]{2}{*}{ Z. costata } & $\mathrm{Zc}$ & 1 & & & & & & & & \\
\hline & $\mathrm{H}$ & 2.32 & 2.19 & 2.10 & 1.77 & 1.59 & 1.56 & 0.64 & 0.00 & 0.00 \\
\hline \multirow[t]{2}{*}{ Shannon } & Variance $\mathrm{H}$ & 0.01 & 0.02 & 0.03 & 0.06 & 0.09 & 0.07 & 0.09 & 0.00 & 0.00 \\
\hline & Exp. H & 10.20 & 8.89 & 8.15 & 5.86 & 4.90 & 4.76 & 1.89 & 1.00 & 1.00 \\
\hline
\end{tabular}

Water f., water fall; Irrigation c., irrigation canal; H, Shannon diversity value; Exp. H, Expected Shannon diversity value. All Sample Index $=2.48$ and Jackknife Standart Error $=0.09$.

factors (Benzie, 1989; Kiss, 2007; Dügel et al., 2008; González-Megías et al., 2011). In the present study, random distributional patterns of ostracods among a variety of sampling sites may be supported by the dominant occurrence of cosmopolitan species (e.g., C. neglecta, D. stevensoni, H. incongruens, I. bradyi, I. gibba (Ramdohr), P. olivaceus, L. inopinata (Baird)) (for the details see Appendix). This is probably due to a wide geographic distribution of cosmopolitans with relatively high tolerance levels to different ecological variables (Külköylüoğlu, 2004). Thus, having such an advantage over non-cosmopolitan species, cosmopolitans can be easily adapted to conditions which may not be suitable for others. Consequently, a relatively higher frequency of 


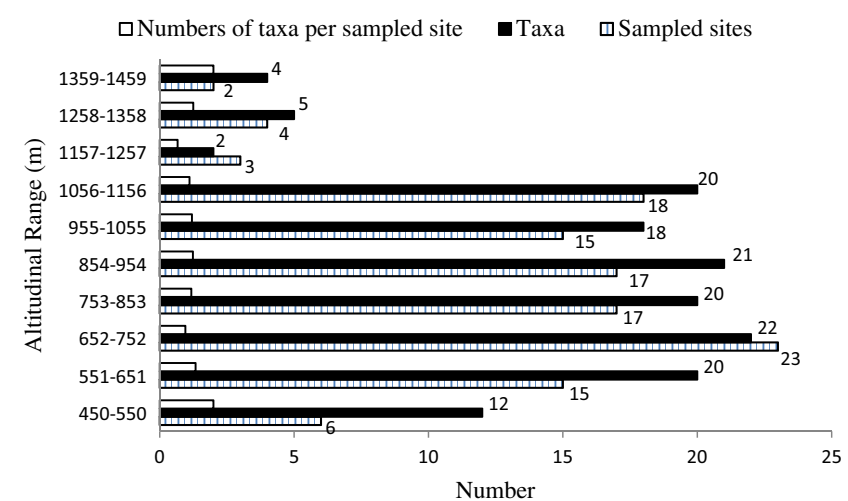

Fig. 4. The numbers of taxa, sites and taxa per sampled site located at $100-\mathrm{m}$ of elevational ranges.

their occurrence may be one of the explanations for finding random distribution of the species among sampling sites. The other important reason for explaining the random distribution of ostracods may be related to their desiccation and freezing resistant eggs (Delorme, 1991). Although the species may die, their eggs can survive in unfavourable conditions for many years until the conditions are appropriate for hatching and the continued survival of the species in the habitat. Having such resistant eggs is a great advantage for ostracods and might contribute to their random distribution in an area. This can also be done by the passive dispersion modes such as human, bird, fish, wind (for prevailing resting eggs), plants, amphibians and insects (McKenzie and Moroni, 1986; Horne and Martens, 1998; Rossi et al., 2003; Rodriguez-Lazaro and Ruiz-Muñoz, 2012). However, because the null hypothesis was accepted, we were not able to test the other distribution patterns (clumped and regular). Thus, such results cannot be generalized at the moment.

Similar to some of the previous studies (e.g., Sarı, 2007; Van der Meeren et al., 2010; Szlauer-Łukaszewska, 2014; Uçak et al., 2014), four species (I. inermis, I. bradyi, $H$. incongruens and $D$. stevensoni) are located relatively closer to the centre of diagram (Fig. 3). Considering that these four species have almost cosmopolitan distribution (also called "cosmoecious species" for their high tolerance levels in wide geographical distribution by Külköylüoğlu (2013)), one may interpret that such variables did not have a critical influence on these species. In contrast, three species ( $H$. intermedia, $P$. similis and $P$. olivaceus) located on the left bottom of the CCA diagram seem to show a negative correlation with the environmental variables used in this analysis. Since ecological data are so scarce about $P$. similis, such knowledge is better for the $H$. intermedia and $P$. olivaceus which displayed relatively lower optimum and tolerance values than the mean values calculated for eight species (Table 4). In stark contrast, Külköylüoğlu and Sarı (2012) showed high tolerance values of $P$. olivaceus to different variables. $H$. intermedia, however, appears to have relatively low tolerance levels for $\mathrm{pH}\left(t_{k}=0.9\right)$, electrical conductivity $\left(t_{k}=299\right)$, water temperature $\left(t_{k}=2.3\right)$ and elevation $\left(t_{k}=171.4\right)$ (Külköylüoğlu et al., 2012b). Unlike $H$. intermedia, $H$. chevreuxi showed higher optimum and tolerance values to temperature than the mean calculated for other species (Table 4), supporting the result of CCA (Fig. 3). Similarly, Roca and Baltanás (1993) and Viehberg (2006) pipointed the preferences and high tolerance of $H$. chevreuxi for temperature. Two other species (C. neglecta and P. fallax) are located nearby the arrow of elevation (Fig. 3). It is already known that C. neglecta has a wide elevational range from $0 \mathrm{~m}$ (Külköylüoğlu et al., 2012c) to $3194 \mathrm{~m}$ a.s.l. (Külköylüoğlu, 2013). Similarly, Poquet and Mesquita-Joanes (2011) illustrated a positive correlation of $C$. neglecta with the elevation. On the other hand, such distribution is limited for P. fallax between 780-1383 $\mathrm{m}$ a.s.1. (this study). This corresponds with the previously known range (605-1954 m a.s.l.) (Külköylüoğlu et al., 2012c; Akdemir and Külköylüoğlu, 2014). Such correlations revealed by the results of CCA partially correspond to the optimum and tolerance values of individual species (Table 4). Even though correlations cannot be counted as causation (Aldrich, 1995), one possible reason (other than biological reasons) of finding different correlations for these species might be related to species individual habitat preferences and conditions (as mentioned above). Indeed, findings of tolerance and optimum levels of the eight most common species (Table 4) implied that individual species showed speciesspecific tolerance and optimum levels to four of the environmental variables. Of which, the species $H$. incongruens has the higher tolerance level for water temperature, while I. bradyi has higher tolerance levels than the mean values of $\mathrm{pH}$, dissolved oxygen, electrical conductivity and temperature (Table 4). Similarly, the previous studies in different geographical areas (Karakaş-Sarı and Külköylüoğlu, 2008; Külköylüoğlu et al., 2013; Uçak et al., 2014) indicated that the tolerance levels of species to different variables can change from species to species. However, such knowledge is limited for most species. For example, F. brevicornis has been reported from slow flowing stagnant water bodies connected to cold spring habitats (Meisch, 2000). Indeed, we found this species from a rheocrene spring where water temperature was $15.3^{\circ} \mathrm{C}$. This value shows similarity with its previously known ranges for temperature from $8.73^{\circ} \mathrm{C}$ (Külköylüoğlu et al., 2014) to $22.6^{\circ} \mathrm{C}$ (Sarı, 2007). Accompanying species, P. fulva prefers shallow, slow flowing waters, cave and interstitial habitats of streams. Therefore, it was characterized as a stygophilic species by Meisch (2000). The ranges of this species are wider than $F$. brevicornis for temperature $\left(27.40-1.56^{\circ} \mathrm{C}\right)$ (Sarl, 2007; Külköylüoğlu et al., 2007).

Based on the results of the CCA, the elevation was among the most four effective factors but we did not find a significant effect of elevation on the species occurring at different elevational ranges (Fig. 4). This is because of the ratio (taxa per sampled site) at the lower and higher elevational ranges equal to each other and the ratio from 551 to $1156 \mathrm{~m}$ a.s.l. were also closer to each other (Fig. 4). 
Although there is a conflict about the role of elevation on species (Mezquita et al., 1999; Laprida et al., 2006; Külköylüoğlu et al., 2012c; Külköylüoğlu, 2013), based on the results we accept that the elevation may play a secondary role on species distribution. For example, since water temperature decreases as the elevation increases, constituents of many physico-chemical characteristics of water (e.g., oxygen, $\mathrm{pH}$ and solid materials) can be changed (Reeves et al., 2007). Such changes can eventually affect the species. In this case, species with higher tolerances can increase their overall distribution better than the other species.

Values of Shannon diversity index of spring, creek and ponds (Table 5) in here are higher than those previously reported for the flowing waters of Eastern Iberian Peninsula $(H=0.826 \pm 0.533)$ (Mezquita et al., 1999) and for a shallow lake (Lake Świdwie) $(H=1.668)$ in Poland (Szlauer-Łukaszewska, 2012). These differences may be associated with the differences in sampling time, numbers and types of sampling sites and geographical differences. On the other hand, a study (Külköylüoğlu et al., 2012b) done in Kahramanmaraş (Turkey) showed similar results with ours that the authors arranged the sites with their high diversity values as limnocrene spring $(H=2.89)$, pond $(H=2.2)$, stream $(H=2.08)$ and creek $(H=1.95)$. Overall, the studies mentioned above, pond, spring and creek may be better and suitable habitats for ostracods reported herein.

\section{Conclusion}

Finally, our results suggest that ostracods (especially cosmopolitans) have a high tendency for a random distribution. Külköylüoğlu (2013) used a new term "cosmoecious species" for those cosmopolitans with wide geographical distribution and relatively high tolerance levels to different environmental variables. Therefore, it seems that cosmopolitans gaining better opportunity for feeding and reproduction than non-cosmopolitans in variety of habitats contribute more on the random distribution. At least three results of the present study support this idea as: (i) finding most of the cosmopolitan species closer to the centre of the CCA diagram (Fig. 3); (ii) encountering well-known cosmopolitans (e.g., H. incongruens and I. bradyi) from lowest $(450-550 \mathrm{~m})$ to highest (1359-1459 m, Fig. 4) elevational ranges; and (iii) wider occurrences in different habitats (Table 5). It appears that if conditions are suitable for ostracods, they can be found in many kinds of aquatic habitats. Thus, it is most likely true that neither regional (spatial) (e.g., elevation, habitat type) nor local factors (e.g., water temperature, $\mathrm{pH}$ and $\mathrm{EC}$ ) are critically effective on most cosmopolitan species. However, since non-cosmopolitan species prefer certain types of habitat conditions, local factors seem to be more important drivers than regional factors. On the other hand, these results cannot be generalized at the moment due to lack of studies on the subject of Poisson distribution on ostracods.
Acknowledgements. We would like to give our sincere appreciation to Randy Gibson (Aquatic Resources Center, USFWS, Texas, USA) for his help in English and comments on the first draft. Also, Mr. Mahmut Kanaç is kindly thanked for his help and guidance during field work. This study was supported by the Scientific Project Research Agency of Abant İzzet Baysal University (Project no: 2012.03.01.534). This is a part of Ph.D. dissertation of M.Y.

\section{References}

Adıyaman valiliği, 2014. Available online at: http://www. adiyaman.gov.tr/AdiyamanIlimiz.aspx?GrupId = 1 (8 January 2014).

Akdemir D. and Külköylüoğlu O., 2011. Freshwater Ostracoda (Crustacea) of Diyarbakır Province, including a new report for Turkey. Turk. J. Zool., 35/5, 671-675.

Akdemir D. and Külköylüoğlu O., 2014. Preliminary study on distribution, diversity, and ecological characteristics of nonmarine Ostracoda (Crustacea) from the Erzincan region (Turkey). Turk. J. Zool., 38, 421-431.

Aldrich J., 1995. Correlations genuine and spurious in Pearson and Yule. Stat. Sci., 10/4, 364-376.

Benzie J.A.H., 1989. The distribution and habitat preference of Ostracods (Crustacea: Ostracoda) in a Coastal Sand-dune Lake, Loch of Strathbeg, North-east Scotland. Freshwat. Biol., 22, 309-321.

Birks H.J.B., Line J.M., Juggins S., Stevenson A.C. and ter Braak C.J.F., 1990. Diatoms and $\mathrm{pH}$ reconstruction. Philos. Trans. R. Soc., 327, 263-278.

Boomer I. and Gearey B., 2010. The occurrence of a new species of Gomphocythere (Ostracoda, Limnicytheridae) in the Holocene of SE Turkey: the Northernmost record for the genus. J. Micropalaeontol., 29, 115-118.

Bronhstein Z.S., 1947. Fresh-water Ostracoda. Fauna of the USSR, Crustaceans, V.2. No.1. Russian Translation Series, 64, Academy of Sciences of the USSR Publishers, Moscow, Russia (English translation 1988); Amerind Publishing Company, New Delhi.

Delorme L.D., 1991. Ostracoda. In: Thorpe J.H. and Covich A.P. (eds.), Ecology and Classification of North American Invertebrates, Academic Press, New York, 691-722.

Dügel M., Külköylüoğlu O. and Kılıç M., 2008. Species assemblages and habitat preferences of Ostracoda (Crustacea) in Lake Abant (Bolu, Turkey). Belg. J. Zool., 138/1, 50-59.

Elliott J.M., 1973. Some Methods for the Statistical Analysis of Samples of Benthic Invertebrates, Scientific Publication No. 25, Freshwater Biological Association, Ambleside, Westmorland, Great Britain.

Gabbutt P.D., 1961. The distribution of some small mammals and their associated fleas from central Labrador. Ecology, $42 / 3,518-525$.

González-Megías A., Gómez J.M. and Sánchez-Pinéro F., 2011. Spario-temporal change in the relationships between habitat heterogeneity and species diversity. Acta Oecol., 37, 179-186.

Heip C., 1975. On the significance of aggregation in some benthic marine invertebrates. In: Proceeding of 9th European Marine Biology Symposium, 527-538.

Heip C., 1976. The spatial pattern of Cyprideis torosa (Jones, 1850) (Crustacea: Ostracoda). J. Mar. Biol. Assoc. UK, 56, 179-189. 
Horne D.J. and Martens K., 1998. An assessment of the importance of resting eggs for the evolutionary success of Mesozoic non-marine Cypridoidean Ostracoda (Crustacea). Arch. Hydrobiol. Spec. Issues Adv. Limnol., 52, 549-561.

Hurlbert S.T., 1984. Pseudoreplication and the design of ecological field experiments. Ecol. Monogr., 54/2, 187-211.

Juggins S., 2003. Software for Ecological and Palaeoecological Data Analysis and Visualization - C2 User Guide, University of Newcastle, Newcastle-upon-Tyne, UK.

Kan İ., 2006. Biyoistatistik (4th edn.), Nobel Yayın, Ankara.

Karakaş-Sarı P. and Külköylüoğlu O., 2008. Comparative ecology of Ostracoda (Crustacea) in two rheocrene springs (Bolu, Turkey). Ecol. Res., 23, 821-830.

Karanovic I., 2012. Recent Freshwater Ostracods of the World, Springer-Verlag, Berlin, Heidelberg, 608 p.

Karuthapandi M., Rao D.V. and Innocent B.X., 2014. Freshwater Ostracoda (Crustacea) of India - a checklist. J. Threatened Taxa, 6/12, 6576-6581.

Kiss A., 2007. Factors effecting spatial and temporal distribution of Ostracoda assemblages in different macrophyte habitats of a shallow lake (ake Fehér, Hungary). Hydrobiologia, 585, 89-98.

Külköylüoğlu O., 2004. On the usage of Ostracoda (Crustacea) as bioindicator species in the different aquatic habitats in the Bolu Region, Turkey. Ecol. Indic., 4, 139-147.

Külköylüoğlu O., 2013. Diversity, distribution and ecology of nonmarine Ostracoda (Crustacea) in Turkey: application of pseudorichness and cosmoecious species concepts. Recent Res. Dev. Ecol., 4, 1-18.

Külköylüoğlu O. and Sarı N., 2012. Ecological characteristics of the freshwater Ostracoda in Bolu Region (Turkey). Hydrobiologia, 688, 37-46.

Külköylüoğlu O., Dügel M. and Kılıç M., 2007. Ecological requirements of Ostracoda (Crustacea) in a heavily polluted shallow lake, Lake Yeniçağa (Bolu, Turkey). Hydrobiologia, $585,119-133$.

Külköylüoğlu O., Sarı N., Akdemir D., 2012a. Distribution and ecological requirements of ostracods (Crustacea) at high altitudinal ranges in Northeastern Van (Turkey). Ann. Limnol. - Int. J. Lim., 48, 39-51.

Külköylüoğlu O., Yavuzatmaca M., Akdemir D. and Sarı N., 2012b. Distribution and local species diversity of freshwater Ostracoda in relation to habitat in the Kahramanmaraş Province of Turkey. Int. Rev. Hydrobiol., 97/4, 247-261.

Külköylüoğlu O., Sarı N., Akdemir D., Yavuzatmaca M. and Atınbağ C., 2012c. Distribution of sexual and asexual Ostracoda (Crustacea) from different altitudinal ranges in the Ordu Region of Turkey: testing the Rapoport rule. High Alt. Med. Biol., 13/2, 126-136.

Külköylüoğlu O., Akdemir D., Sarı N., Yavuzatmaca M., Oral C. and Başak E., 2013. Distribution and ecology of Ostracoda (Crustacea) from troughs in Turkey. Turk. J. Zool., 37, 277-287.

Külköylüoğlu O., Sarı N., Dügel M., Dere Ş., Dalkıran N., Aygen C. and Çapar Dinçer S., 2014. Effects of limnoecological changes on the Ostracoda (Crustacea) community in a shallow lake (Lake Çubuk, Turkey). Limnologica, 46, 99-108.

Laprida C., Díaz A. and Ratto N., 2006. Ostracods (Crustacea) from thermal waters, Southern Altiplano, Argentina. Micropaleontology, 52, 177-188.
Ludwig J.A. and Reynolds J.F., 1988. Statistical Ecology - a Primer on Methods and Computing, John Wiley \& Sons, New York, 337 p.

Malmqvist B., Meisch C. and Nilsson A.N., 1997. Distribution patterns of freshwater Ostracoda (Crustacea) in the Canary Island with regards to habitat use and biogeography. Hydrobiologia, 347, 159-170.

Martens K., 1993. On the taxonomy and zoogeography of the genus Gomphocythere Sars, 1924 (Crustacea, Ostracoda), with the description of a new species from the Nahal Dan (Israel). Belg. J. Zool., 123/1, 39-54.

McKenzie K.G. and Moroni A., 1986. Man as a agent of crustacean passive dispersal via useful plants: exemplified by Ostracoda ospiti esteri of the Italian Ricefields ecosystem: and implications arising therefrom. J. Crustacean Biol., 6/2, 181-198.

Meisch C., 2000. Freshwater Ostracoda of Western and Central Europe, Spektrum Akademischer Verlag, Heidelberg, Süßwasserfauna von Mitteleuropa, 8, I-xii, 522 p.

Mezquita F., Griffiths H.I., Sanz S., Soria J.M. and Pinon A., 1999. Ecology and distribution of Ostracods associated with flowing waters in the Eastern Iberian Peninsula. J. Crustacean Biol., 19, 344-354.

Morisita M., 1959. Measuring of dispersion of individuals and analysis of the dispersal patterns. Memoirs of the Faculty of Science, Kyushu University, Series, E2, 215-235.

Pieri V., Martens K., Stoch F. and Rossetti G., 2009. Distribution and ecology of non-marine ostracods (Crustacea, Ostracoda) from Friuli Venezia Giulia (Ne Italy). J. Limnol., 68/1, 1-15.

Pieri V., Martens K., Meisch C. and Rossetti G., 2013. An updated checklist of the recent non-marine Ostracods (Crustacea Ostracoda) from Italy. IL Naturalista Siciliano, XXXVII/1, 273-276.

Poquet J.M. and Mesquita-Joanes F., 2011. Combined effects of local environment and continental biogeography on the distribution of Ostracoda. Freshwat. Biol., 56, 448-469.

Reeves J.M., De Deckker P. and Halse S.A., 2007. Groundwater Ostracods from the Arid Pilbara Region of Northwestern Australia: distribution and water chemistry. Hydrobiologia, 585, 99-118.

Roca J. and Baltanás A., 1993. Ecology and distribution of Ostracoda in Pyrenean springs. J. Crustacean Biol., 13/1, 165-174.

Rodriguez-Lazaro J. and Ruiz-Muñoz F., 2012. A general introduction to ostracods: morphology, distribution, fossil record and applications. In: Horne D.J., Holmes J.A., Rodriguez-Lazaro J. and Viehberg F.A. (eds.), Development in Quaternary Science, Ostracoda as Proxies for Quaternary Climate Change, Elsevier, Amsterdam, 1-14.

Rossi V., Benassi G., Veneri M., Bellavere C., Menozzi P. and Moroni A., 2003. Ostracoda of the Italian ricefields thirty years on: new synthesis and hypothesis. J. Limnol., 62, 1-8.

Sarı N., 2007. Determination of ecological features of the freshwater Ostracoda (Crustacea) in Bolu Region (Turkey). MSc Thesis, Abant İzzet Baysal University, Bolu, p. 121.

Sarı N. and Külköylüoğlu O., 2010. Ostracods (Crustacea) and habitat similarities in the Bolu Region (Turkey). Turk. J. Zool., 34, 225-230.

Schmidt G.H., 1982. Random and aggregative settlement in some sessile marine invertebrates. Mar. Ecol-Prog. Ser., 9, $97-100$ 
Seaby R.M. and Henderson P.A., 2006. Species Diversity and Richness, Version 4, Pisces Conservation Ltd., Lymington, UK.

Szlauer-Łukaszewska A., 2012. Ostracod assemblages in relation to littoral plant communities of a shallow lake (Lake Świdwie, Poland). Int. Rev. Hydrobiol., 97/4, 262-275.

Szlauer-Łukaszewska A., 2014. The dynamics of seasonal ostracod density in groyne fields of the Oder River (Poland). J. Limnol., 73/2, 298-311.

Teeter J.W., 1973. Geographic distribution and dispersal of some recent shallow-water marine Ostracoda. Ohio J. Sci., 73/1, 46-54.

ter Braak C.J.F., 1987. The analysis of vegetation-environment relationships by canonical correspondence analysis. Vegetatio, 69, 69-77.
Uçak S., Külköylüoğlu O., Akdemir D. and Başak E., 2014. Distribution, diversity and ecological characteristics of freshwater Ostracoda (Crustacea) in shallow aquatic bodies of the Ankara Region, Turkey. Wetlands, 34, 309-324.

Van der Meeren T., Almendinger J.E., Ito E. and Martens K., 2010. The ecology of Ostracodes (Ostracoda, Crustacea) in Western Mongolia. Hydrobiologia, 641, 253-273.

Viehberg F.A., 2006. Freshwater ostracod assemblages and their relationship to environmental variables in waters from northeast Germany. Hydrobiologia, 571, 213-224.

Yavuzatmaca M., Külköylüoğlu O., Sarı N., Başak E. and Mengi H., 2012. Ostracoda (Crustacea) from freshwater caves in the Western Black Sea Region of Turkey. Cave and Karst Science, 39/2, 53-58.

Zar J.A., 1999. Biostatistical Analysis, Prentice-Hall, Upper Saddle River, New Jersey, 944 p. 


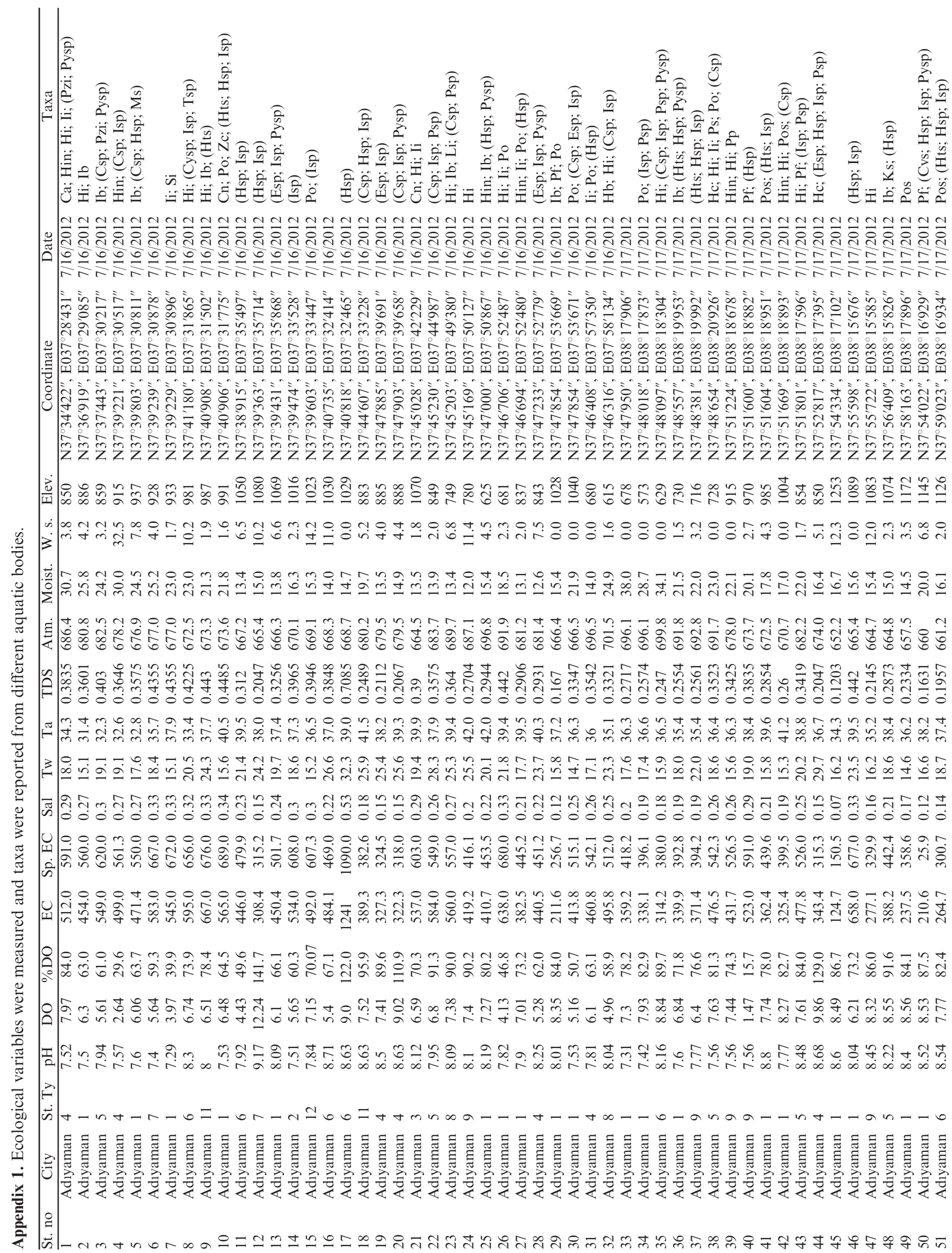




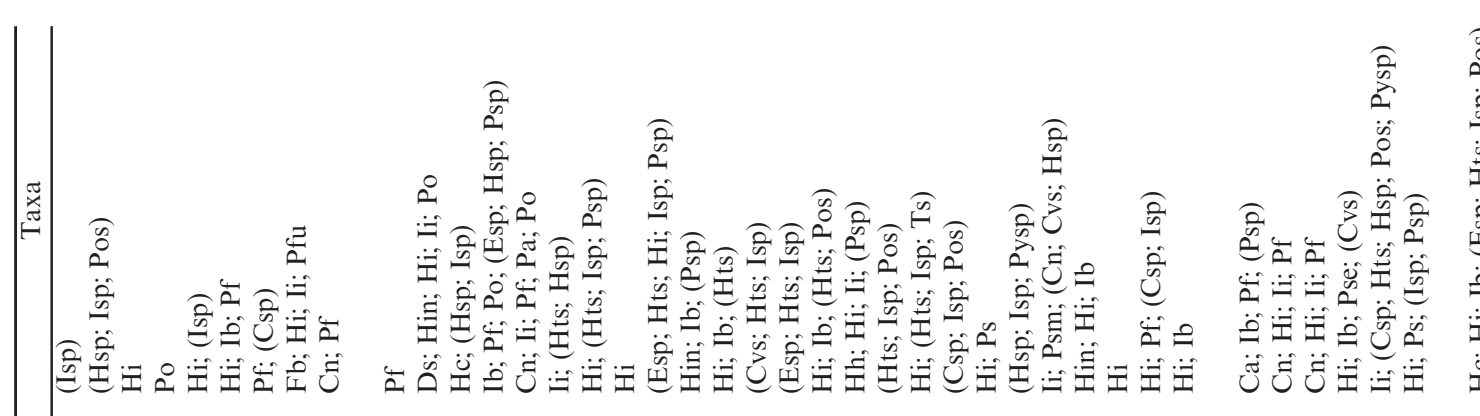

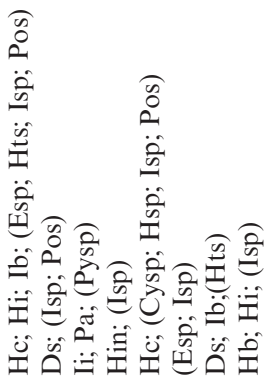

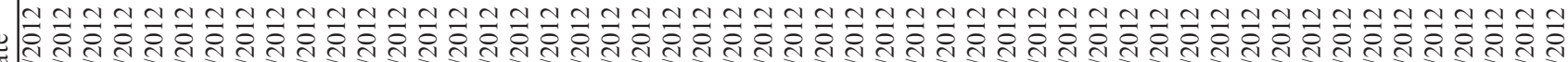

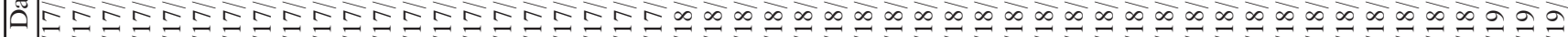

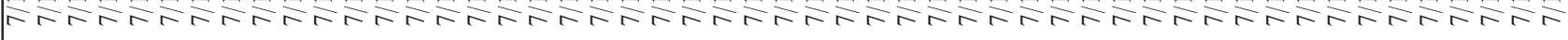

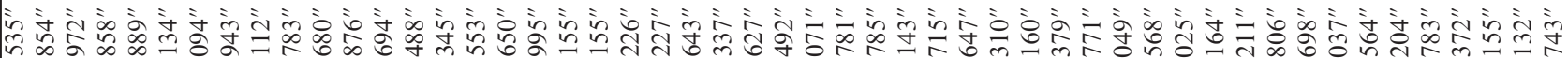

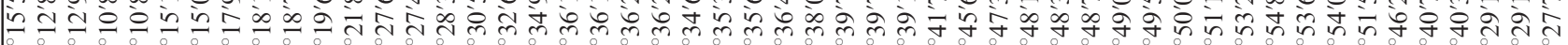

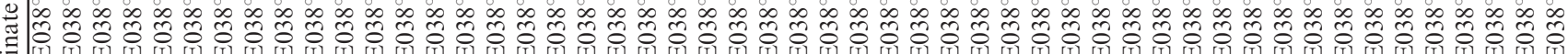

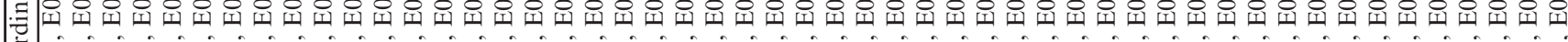

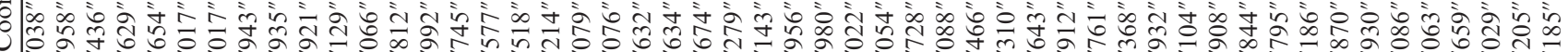

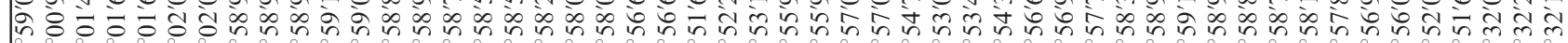

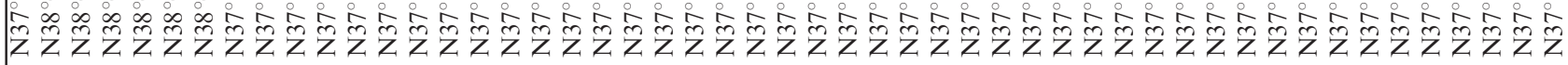

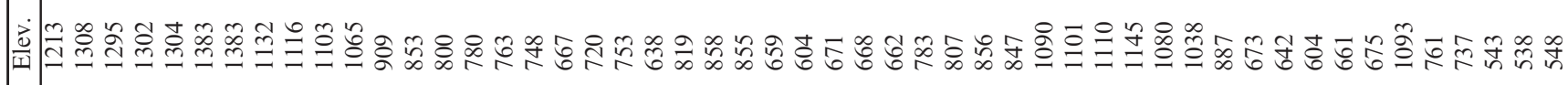

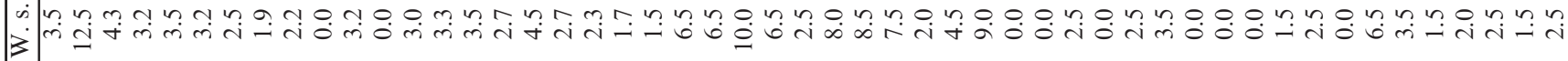
苟

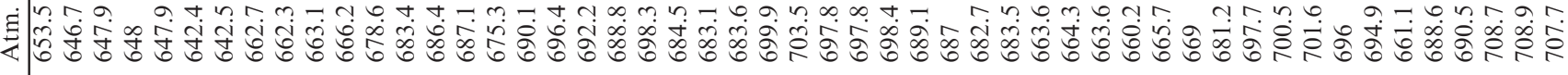

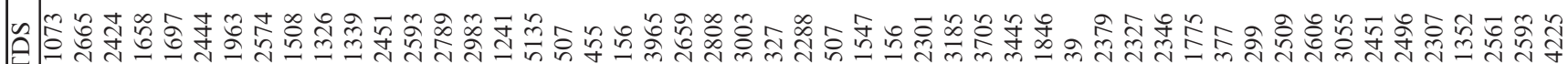

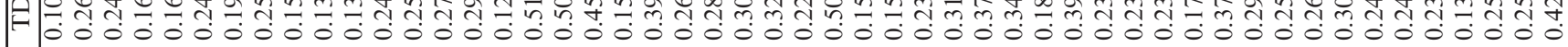

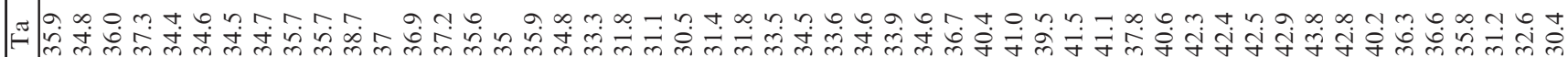

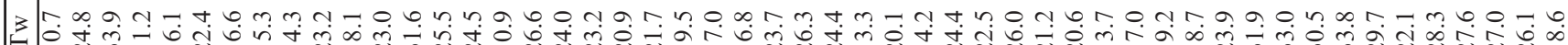
Fचٓ U

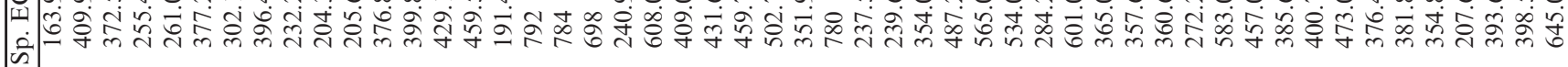

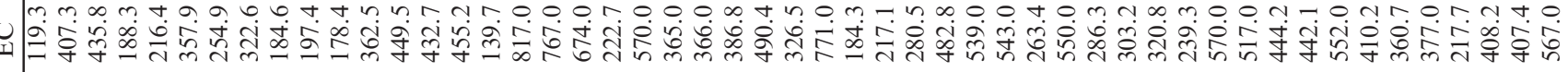

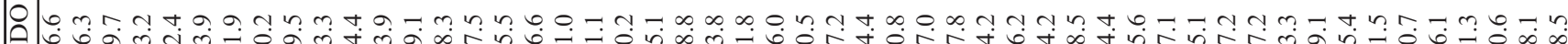

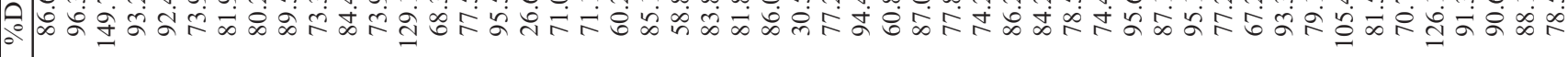

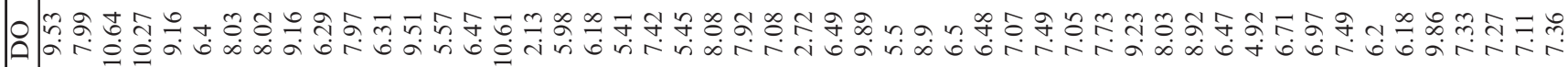

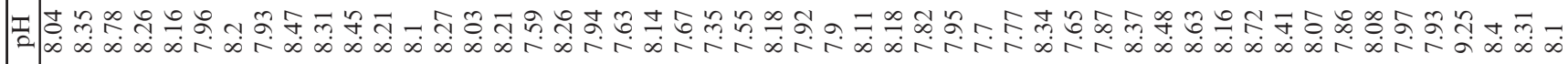

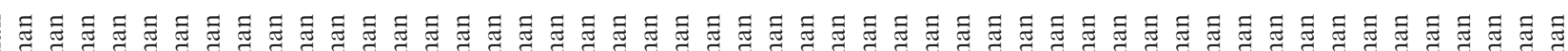

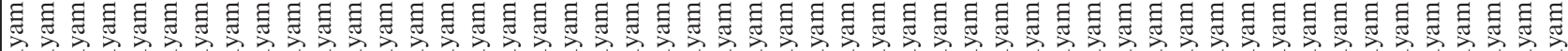

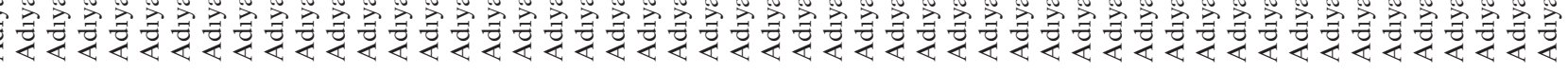




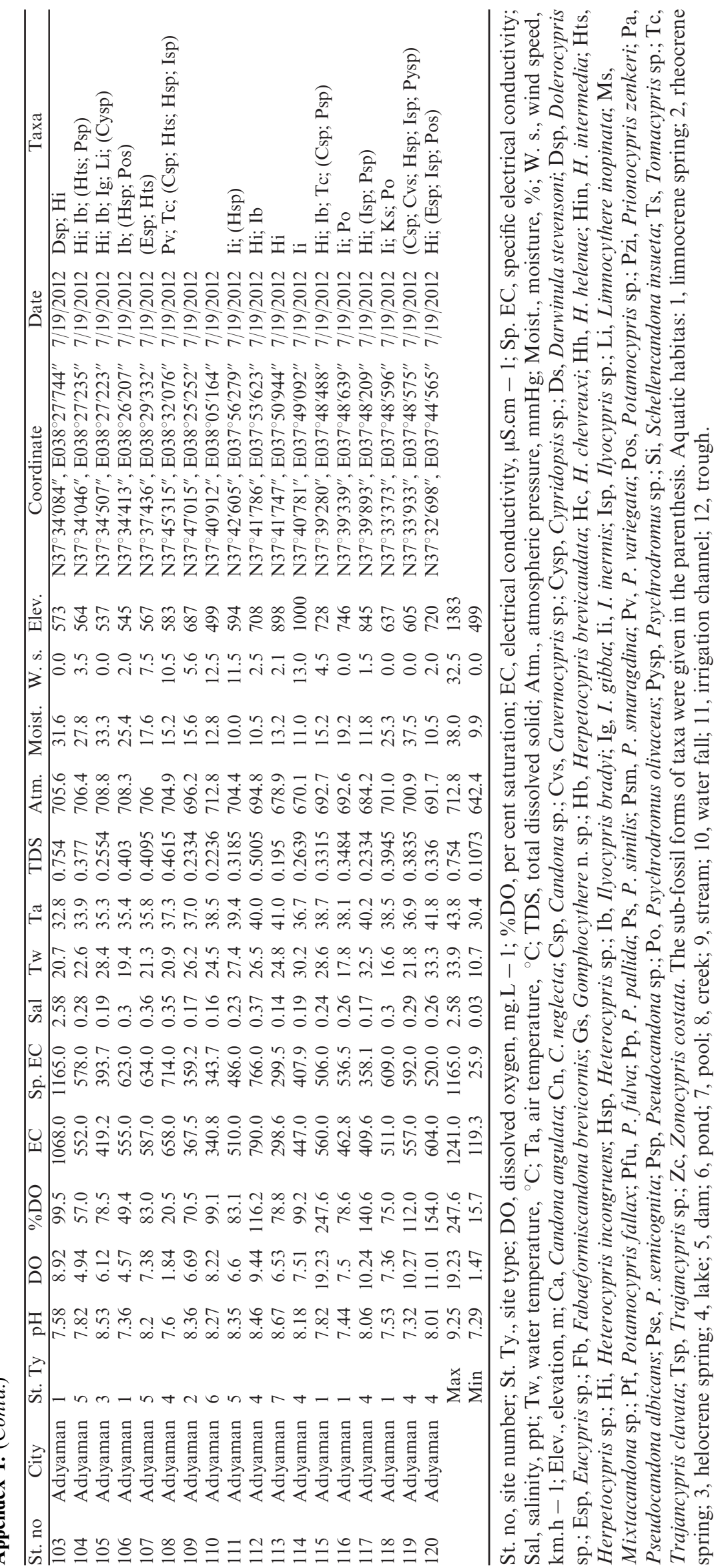

